21 This study evaluated the performance of a micro-aerobic hydrolysis of mixed sludge and its

22 influence as a pretreatment of this waste for its subsequent anaerobic digestion. Three

23 experimental series were carried out to evaluate the optimum micro aeration levels in the
"This is an Accepted Manuscript of an article published by Taylor \& Francis in Journal of Environmental Science and Health Part A on 17 Aug 2016, available online: http://dx.doi.org/10.1080/10934529.2016.1215195

\section{Performance evaluation of micro-aerobic hydrolysis of mixed sludge: Optimum aeration and effect on its biochemical methane potential}

${ }^{1 *}$ Chemical Engineering Department, Universidad de Santiago de Chile, Ave. Lib. Bdo

${ }^{2}$ Chemical and Environmental Engineering Department, Universidad Federico Santa María, Valparaíso, Chile

${ }^{3}$ Instituto de la Grasa (CSIC), Campus Universitario Pablo de Olavide, Edificio 46,

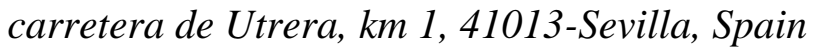

\section{ABSTRACT} range from 0.1 to $0.5 \mathrm{vvm}$ and operation times within the range $24-60 \mathrm{~h}$. The maximum 
26 *Address correspondence to Professor Silvio Montalvo, Chemical Engineering Department

27 University of Santiago de Chile; phone : 56-2-27181826

28 e-mail: silvio.montalvo@usach.cl

29 methane yield (35 $\mathrm{mL} \mathrm{CH}_{4} / \mathrm{g}$ VSS added) was obtained for an aeration level of $0.35 \mathrm{vvm}$.

30 This methane yield value increased $114 \%$ with respect to that obtained with the non-aerated

31 sludge. In the micro aeration process carried out at an aeration level of $0.35 \mathrm{vvm}$, increases

32 in soluble proteins and total sugars concentrations of $185 \%$ and $192 \%$ with respect of their

33 initial values were found respectively after $48 \mathrm{~h}$ of aeration. At the above micro-aerobic

34 conditions, soluble COD augmented $150 \%$ while volatile suspended solids (VSS) content

35 decreased until $40 \%$ of their initial respective values. Higher COD $_{S}$ increases and VSS

36 decreases were found at $60 \mathrm{~h}$ of micro-aeration, however, the above parameters did not vary

37 significantly with respect to the values found at $48 \mathrm{~h}$.

39 Keywords: Aerobic hydrolysis, anaerobic digestion, methane production, mixed sludge.

\section{INTRODUCTION}

43 The anaerobic process, commonly called anaerobic digestion, is the most used 44 treatment technology for organic matter removal from primary and waste activated sludge 45 (WAS). ${ }^{[1-3]}$ The benefits associated with anaerobic technology include mass reduction, odor 46 removal, ${ }^{[4-5]}$ pathogen reduction, and more significantly, energy recovery in the form of 47 methane. ${ }^{[6]}$ However, it should be emphasized that sludge contains 10 times the energy 48 required to treat it. It has been proven to be technically feasible to recover energy from the 
49 sludge, which can be directly used in wastewater treatment or be sold to the network, 50 reducing the facility's dependency on conventional electricity and helping the stressed

51 public budgets. Nevertheless, the anaerobic digestion of sewage sludge has several 52 disadvantages such as relatively low methane production, 30 - $50 \%$ biodegradability and 53 the presence of some inhibitory compounds that make necessary the use of high retention 54 times in the digesters with high mixing costs. ${ }^{[7-9]}$ These limiting factors are generally 55 associated with the hydrolysis stage. ${ }^{[10-11]}$ During hydrolysis, cell walls are ruptured and 56 extracelular polymeric substances (EPS) are degraded resulting in the release of readily 57 available organic material for the acidogenic microorganisms. This mechanism is 58 particularly important in mixed sludge digestion, since the major constituent of its organic 59 fraction are cells, being a relatively unfavorable substrate for microbial degradation.

60 In order to avoid or reduce the existence of the hydrolysis process in the sludge anaerobic 61 digestion several methods have been studied, alone or in combination such as thermal ${ }^{[12-14]}$ 62 , physical-chemical ${ }^{[15-16]}$ and mechanical. ${ }^{[17-18]}$ Some biological methods have been also 63 investigated. ${ }^{[19-20]}$

64 Among biological, the use of micro aeration as a treatment prior to anaerobic digestion has 65 received less attention, even though it has been reported that the limited oxygen supply 66 caused an increase of the enzymatic hydrolysis rates for the case of complex organic matter 67 in batch tests. ${ }^{[21]}$ Results from some micro aerobic research carried out with municipal solid 68 wastes and other wastes suggest that hydrolysis, and therefore, the COD solubilization 69 might be improved by micro aeration. ${ }^{[22-24]}$ However, the presence of oxygen in the 70 anaerobic digestion can also produce a problem regarding to the use and degradation of 71 organic matter. In presence of oxygen, there is a competition by the substrate between 72 facultative and strict anaerobes ${ }^{[25]}$, which could reduce the organic matter available for 
73 methanogenic archaea, because part of the substrate is used for the production of $\mathrm{CO}_{2}$ and

74 biomass by facultative microorganisms. Therefore, the management of micro-aeration

75 should be carefully carry out in order to improve the hydrolytic rate with a minimum

76 consume of organic matter by facultative microorganisms with $\mathrm{CO}_{2}$ and biomass

77 production.

78 Regarding the effect of micro-aeration on sewage sludge anaerobic digestion, few studies

79 have been reported. Jenicek et al. ${ }^{[26]}$, using a continuous bioreactor and pumping air

80 continuously into the sludge recirculation stream, showed that VSS/TSS ratio of the

81 digested sludge, soluble COD concentration, ammonia nitrogen and phosphate

82 concentration decreased in all experiments with micro aerobic conditions. Jenicek et al. ${ }^{[27]}$

83 working with a continuous stirred tank reactor (CSTR) under continuous micro aeration,

84 indicated that efficient $\mathrm{H}_{2} \mathrm{~S}$ removal, higher specific methane production, lower methane

85 concentration in biogas due to dilution by nitrogen remained from the air dosed were

86 achieved in the anaerobic digestion of the pre-aerated sludge, while better sludge liquor

87 quality and lower foaming potential and foam stability were observed in the pre-treated

88 sludge after using micro aeration. Montalvo et al. ${ }^{[28]}$ determined that applying $0.3 \mathrm{vvm}$, and

89 at temperature of $35 \mathrm{C}$ were the best operational conditions increasing hydrolysis rate of

90 mixed sludge. However they did not find the optimum amount of air for hydrolysis nor

91 tested the effect of aerobic hydrolysis to different aeration rates on anaerobic digestion

92 sludge

93 Given this background, the behavior and performance of the micro aerobic hydrolysis of

94 mixed sewage sludge looking for the optimum level of aeration were evaluated in the

95 present research work with the aim of achieving maximum efficiency of hydrolysis. The

96 effect of the micro-aeration level of the mixed sludge on the methane yield was also 
97 evaluated in biochemical methane potential tests carried out at $35^{\circ} \mathrm{C}$ in batch mode,

98 comparing the results obtained with the pre-aerated sludge with those achieved for control

99 sludge without pre-aeration.

100

101 MATERIALS AND METHODS

102

103 Three experimental runs were carried out at laboratory-scale. A summary of the operating

104 conditions assayed in each experimental run is shown in Table 1.

105 The substrate used in all the assays was a mixed sludge (mixture of waste activated sludge

106 and primary sludge). This mixed sludge was obtained from the urban wastewater treatment

107 plant (UWTP) called "La Farfana", which is located in Santiago de Chile city. Each studied

108 experimental run was carried out by duplicate.

109 The experimental run I was performed with one sample of mixed sludge while the

110 experimental series II and III were carried out with four samples of mixed sludge taken

111 during different times along the day with the aim of obtaining more representative results.

112 In the experimental run $\mathrm{I}$, batch reactors of $5 \mathrm{~L}$ of total volume and $4 \mathrm{~L}$ of working volume

113 were used for the micro aeration process. After micro aerobic pretreatment, $200 \mathrm{~mL}$ of

114 pretreated sludge is passed into batch anaerobic digesters of $280 \mathrm{~mL}$ of total volume. After

115 that, $50 \mathrm{~mL}$ of anaerobic inoculum is added to each anaerobic digester. The anaerobic

116 inoculum came from the anaerobic plants that digest waste activated sludge at "La Farfana"

117 UWTP. This anaerobic inoculum had a VSS concentration of $10 \mathrm{~g} / \mathrm{L}$ and a specific

118 methanogenic activity of $0.32 \mathrm{~g} \mathrm{COD}-\mathrm{CH}_{4} /(\mathrm{g}$ VSS $\cdot \mathrm{d})$. The anaerobic digesters were sealed

119 and headspace flushed with $\mathrm{N}_{2}$ at the beginning of the test. The produced biogas was

120 measured by liquid displacement after going through a 3\% (w/w) $\mathrm{NaOH}$ solution to capture 
121 the produced $\mathrm{CO}_{2}$; the remaining gas was assumed to be only methane. The anaerobic tests 122 were run for a period of c.a. 20-25 days until the accumulated gas production remained 123 essentially unchanged, i.e. on the last day production was lower than $3 \%$ of the 124 accumulated methane produced. The main objective of this experimental run was to obtain 125 the best aeration level within the range from 0.1 to $0.5 \mathrm{vvm}$ (volume of air/(volume of 126 reactor $\cdot$ minute)) taken into account as criterion the methane production achieved in the 127 batch anaerobic digestion experiment of the pre-aerated sludge. The experiment 128 corresponding to an aeration level of $0.3 \mathrm{vvm}$ was extended until $60 \mathrm{~h}$ with the aim of 129 assessing the evolution of proteins and total sugars with time.

130 The experimental run II had two main objectives: firstly, to obtain the optimum aeration 131 level and, secondly, to assess the influence of aeration time on the hydrolysis process. After 132 this run, no batch anaerobic digestion experiments of the pre-aerated sludge were made.

133 Finally in the experimental run III, the performance of the micro-aerated hydrolysis was 134 evaluated from the evolution of different parameters such as soluble proteins and sugars 135 with time and its influence on the methane production of the pre-aerated sludge. In this run 136 II, it was used the best aeration level obtained in the second experimental run $(0.35 \mathrm{vvm})$.

137 The operating temperature selected for the micro aerobic hydrolysis experiments was $35^{\circ} \mathrm{C}$ 138 according to previous results reported in the literature. ${ }^{[28]}$ This temperature was also used 139 for batch anaerobic digestion experiments of the pretreated sludge because it coincides with 140 the optimum temperature reported for achieving maximum methane production within the 141 mesophilic interval. ${ }^{[7]}$

142 All chemical analysis were determined according to American Public Health Association 143 Standard Methods. ${ }^{[29]}$ Specifically, chemical oxygen demand (COD) and volatile suspended 144 solids were analysed according to the closed digestion and colorimetric 5220D method and 
145 2540B method, respectively of the Standard Methods (APHA, 2012). ${ }^{[29]} \mathrm{pH}$ was determined 146 using a pH-meter model Crison 20 Basic.

147 Soluble proteins and total sugars were determined using the ASTM D5712 and ASTM 148 D6406 standard methods, respectively.

149 For the statistic processing and analysis of the data, the software Minitab 8 was utilized. An 150 ANOVA analysis was done and a comparison of confidence intervals for mean values was 151 made with a confidence of $95 \%$.

153 RESULTS AND DISCUSSION

155 No significant differences in the behavior of duplicate reactors were observed in all assays. 156 Therefore, only the results of one of the duplicate reactors will be shown.

160 Figure 1 shows the evolution of the methane production (measured as $\mathrm{mL}$ methane/g of 161 volatile suspended solids (VSS) added), which will allow to assess the variation of the 162 accumulated methane with time per each gram of VSS added at the beginning of the 163 anaerobic digestion process.

164 As can be seen for an aeration level of 0.1 vvm only a small increase in methane production 165 was observed compared to the control (not subjected to aeration). An ANOVA analysis of 166 the data revealed that this difference in production of methane was not statistically 167 significant with a confidence level of $95 \%$. In this case, the following values of statistical 168 parameters were obtained: $\mathrm{F}=0.141 ; \mathrm{p}=0.709 ; \mathrm{F}_{\text {critical }}=4.130\left(\mathrm{~F}_{\text {critical }}\right.$ value was higher than 
169 F). By contrast, for an aeration level of $0.3 \mathrm{vvm}$ an increase of $114 \%$ in the methane 170 production of the pre-aerated sample was achieved compared to the control without 171 aeration. In this case, the difference was statistically significant as was shown in the 172 statistical analysis $\left(\mathrm{F}=6.789 ; \mathrm{p}=0.013 ; \mathrm{F}_{\text {critical }}=4.149\right)$. Finally, for the experimental run 173 of $0.5 \mathrm{vvm}$, no significant differences between the methane production of the pre-aerated 174 sludge and the control were detected $\left(\mathrm{F}=0.044 ; \mathrm{p}=0.834 ; \mathrm{F}_{\text {critical }}=4.130\right)$, which 175 demonstrates that a high aeration may not be beneficial, and, even, harmful for the 176 anaerobic digestion process.

177 Therefore, according to these results an aeration level of $0.3 \mathrm{vvm}$ contributes to better 178 performance of methanogenic microorganisms confirmed by the methane production 179 obtained in this case. When the aeration level increased up to $0.5 \mathrm{vvm}$ a decrease in 180 methane production was observed as consequence of the higher concentration of dissolved 181 oxygen, which inhibited the metabolism and activity of methanogens. Gerritse and 182 Gottschal $^{[30]}$ demonstrated that an aeration level of 0.1 vvm did not increase the methane 183 formation compared to a control sample. However, a short time of exposure to oxygen did 184 not reduce the methanogenic activity and under these conditions the methanogens can 185 survive more time than previously expected. ${ }^{[31]}$ For instance, oxygen concentration levels 186 in the range of $4.9-6.4 \mathrm{mg} / \mathrm{L}$ are required to inhibit $50 \%$ of the methanogenic activity. ${ }^{[32]}$ 187 All these results clearly indicated that an adequate optimization of oxygen supply to 188 aeration is required in all cases to avoid the inhibition of methanogenic activity.

189 As was shown in Figure 1, the maximum methane yield (35 $\mathrm{mL} \mathrm{CH}_{4} / \mathrm{g}$ VSS added) was 190 obtained for an aeration level of $0.3 \mathrm{vvm}$. This value represents an increase of $114 \%$ in 191 methane production compared to that obtained with the non-aerated sludge. This increase in 192 the methanogenic activity is attributed to an improvement in the growth of facultative 
193 anaerobic microorganisms, which can keep a low redox potential, providing the best

194 conditions for the growth of strict anaerobes. ${ }^{[23]}$

195 Table 2 shows the effect of aeration on the final $\mathrm{pH}$ of the reactors. As can be seen, a $\mathrm{pH}$

196 increase of $7.1 \%$ and $3.2 \%$ was achieved in the reactors with aeration and non-aeration,

197 respectively. This $\mathrm{pH}$ increase can be due to two main factors: firstly, the hydrolysis of

198 proteins produces the liberation of amino groups $\left(-\mathrm{NH}_{2}\right)$, which are converted into

199 ammonia $\left(\mathrm{NH}_{3}\right)$, which when is dissolved generates ammonium $\left(\mathrm{NH}_{4}{ }^{+}\right)$and hydroxyl ions

$200\left(\mathrm{OH}^{-}\right)$, causing a $\mathrm{pH}$ increase. ${ }^{[33]}$ Second, when micro-aeration is applied, a $\mathrm{CO}_{2}$ stripping

201 takes place by the air supplied to the process.

202 Figures 2 shows the evolution of the soluble proteins (measured as equivalent concentration

203 of bovine serum albumin, BSA) during the micro-aeration process at $0.3 \mathrm{vvm}$ of the three 204 samples of sludge.

205 As can be seen in Figure 2, an increase in the soluble proteins of $185 \%$ was observed after $20648 \mathrm{~h}$ of aeration (at $0.3 \mathrm{vvm}$ ), while that an increase of only $7.8 \%$ was detected in the non-

207 aerated reactor. The evolution of the soluble proteins with time had a behavior of bell208 shaped, achieving a maximum value at $48 \mathrm{~h}$ of aeration. This behavior can be explained 209 taking into consideration that a part of the mixed sludge is composed by waste activated 210 sludge, which consisted of flocs formed by clusters of cells and organic matter within a 211 viscous material. For this reason, there was an increase in soluble proteins until $48 \mathrm{~h}$, which 212 were released and at the same time the insoluble proteins retained in the flocs could also be 213 solubilized. This process is called de-flocculation, and is caused, among other factors, by a 214 decrease in the aeration of the activated sludge process, reducing the amount of dissolved 215 oxygen, which coincides with the operating parameters in the present work, where low air 
216 flows were injected, causing the low amount of dissolved oxygen in the reactors, its

217 concentration was found to be zero in all measurements carried out.

218 Another possible explanation of the increase in the protein concentration during the first 48

$219 \mathrm{~h}$ of aeration is the solubilization of insoluble proteins found in the organic matter of the

220 sludge by proteases enzymes.

221 Finally, once the maximum protein concentration was achieved at $48 \mathrm{~h}$, a decrease in the

222 protein content was observed due to its degradation by non-hydrolytic bacteria.

223 Figure 3 shows evolution of total sugars (measured as equivalent concentration of glucose).

224 As it is known hydrolysis is the rate-limiting step for the carbohydrates conversion. ${ }^{[34]}$

225 Therefore, the total sugar concentration also increased in a similar manner during the first

$22648 \mathrm{~h}$ of aeration, obtaining an increase of $192 \%$ with respect of its initial value (Figure 3 ).

227 This rise can be mainly attributed to the hydrolysis of polysaccharides to monosaccharides

228 when micro-aeration is applied, which is extremely beneficial for anaerobic digestion. A

229 maximum value in the sugar concentration was achieved at $48 \mathrm{~h}$ of aeration, after which a

230 soft decrease was detected. This may be attributed to a certain conversion of

231 polysaccharides after this time and the beginning of the transformation of the

232 monosaccharides. By contrast, the increase in the total sugars in the non-aerated reactor

233 was only of $3 \%$.

234 Table 3 summarizes the values of the concentration of total ammonia (TAMON), total

$235 \mathrm{COD}\left(\mathrm{COD}_{\mathrm{T}}\right)$, soluble $\mathrm{COD}\left(\mathrm{COD}_{\mathrm{S}}\right)$ and VSS (average of the three samples of mixed

236 sludge $)$ after micro-aeration $(0.3 \mathrm{vvm})$ during $48 \mathrm{~h}$ and after non-aeration conditions.

237 The results shown in Table 3 indicate that the micro aeration process of mixed sludge

238 influence the significant increase of ammonia nitrogen, which is due to the hydrolysis of

239 proteins and their further conversion to amino-acids and ammonia nitrogen. This agrees 
240 with the increase of $\mathrm{pH}$ from 5.8 to 6.0-6.2, which results beneficial for the anaerobic

241 digestion process of the pre-aerated sludge. Despite the increase in ammonia concentration

242 up to values of $920 \mathrm{mg} / \mathrm{L}$, this value cannot be considered as toxic o inhibitory for

243 anaerobic process, whose values range from $1500-3000 \mathrm{mg} / \mathrm{L}^{[35-36]}$ The $\mathrm{COD}_{\mathrm{S}}$ also

244 increased both in the non-aerated as in the micro-aerated reactors. However, in the reactors

245 with micro-aeration, the $\mathrm{COD}_{\mathrm{S}}$ increased $150 \%$ with respect of its initial value, while in the

246 non-aerated ones this increase was only of $27 \%$. These values showed that micro-aeration

247 promotes the hydrolysis of the complex organic matter and its conversion to soluble matter

248 with a considerable rise of the $\mathrm{COD}_{\mathrm{S}}$ as a result of the enzymatic reaction. ${ }^{[37]}$

249 On the other hand, the $\mathrm{COD}_{\mathrm{T}}$ experimented a relatively small decrease in both cases

250 studied, being this decrease quite less for the non-aerated reactor. This implies that the

251 complex organic matter can be transformed into more simple matter but never to develop a

252 removal process of organic matter aerobically, which would imply a much higher energy

253 expenditure.

254 Finally, the VSS concentration also decreased in all reactors, although this decrease was

255 quite higher in the micro-aerated reactors (40\%) compared to that achieved in the control

256 reactors $(11 \%)$. This again shows the micro-aeration promote the hydrolysis of the complex

257 organic matter, and this matter is precisely the substrate of enzymatic reaction. ${ }^{[38]}$

259 Assay II

261 Figure 4 shows the evolution of the $\mathrm{COD}_{\mathrm{S}}$ with time for each one of the four samples of

262 mixed sludge (A, B, C and D) subjected to micro-aerobic hydrolysis using aeration levels 263 of $0.3,0.35,0.4,0.45$ and $0.5 \mathrm{vvm}$. As can be seen, an increase in $\mathrm{COD}_{\mathrm{S}}$ with the aeration 
264 time was observed in most cases. Specifically, increases in $\mathrm{COD}_{\mathrm{S}}$ of between $100 \%$ and $265383 \%$ were observed for the three experimental runs carried out (Figures 8 B, C and D) 266 when the aeration intensity increased from 0.3 to $0.5 \mathrm{vvm}$. Therefore, when aeration was 267 increased between the mentioned values, the $\mathrm{COD}_{\mathrm{S}}$ was at least doubled. For the best 268 aeration level tested $(0.35 \mathrm{vvm})$ an increase in the solubility from $8 \%$ to $23 \%$ was obtained

269 when the aeration time increased from 48 to $60 \mathrm{~h}$.

270 The variation of the VSS with time for the four experimental runs carried are with different

271 aeration intensities is shown in Figure 5. A decrease in the VSS content was observed for 272 all the cases studied. VSS reduction percentages in the range from $11.5 \%$ to $23.6 \%$ were 273 achieved after $60 \mathrm{~h}$ of aeration. This reduction represents the decomposition of the complex 274 organic matter that is transformed in the substrate of the hydrolytic reactions. The highest 275 VSS removal was reached with an aeration level of $0.35 \mathrm{vvm}$. Therefore, the use of a 276 controlled aeration with a specific aeration level allow eliminating certain non277 biodegradable compounds or compounds more difficult to biodegrade using only anaerobic 278 digestion. $^{[39]}$ VSS reductions of between 2-5\% were only reached between the 48 and $60 \mathrm{~h}$ 279 of aeration for the experiments carried out with an aeration level of $0.35 \mathrm{vvm}$.

280 Finally, the VSS removal percentages obtained at an aeration level of $0.35 \mathrm{vvm}(23.6 \%)$

281 were higher than others reported in the literature using an increase of temperature between 28240 and $50^{\circ} \mathrm{C}(20 \%$ VSS reduction $)$ instead of a micro-aeration step. ${ }^{[40]}$

284 Assay III

286 Figure 6 shows the variation of the $\mathrm{COD}_{\mathrm{T}}$ with time during the anaerobic digestion 287 processes of the non-aerated sludge (control) and micro-aerated sludge at 0.35 vvm. As can 
288 be seen a higher $\mathrm{COD}_{\mathrm{T}}$ removal efficiency was always observed for the micro-aerated 289 sludge compared to the control, being the final $\mathrm{COD}_{\mathrm{T}}$ removal efficiency for the pre-aerated 290 sludge at $23^{\text {th }}$ day of digestion time $17 \%$ higher than for the control, difference that can be 291 considered statistically significant.

292 Figure 7 illustrates the variation of the VSS with digestion time for the anaerobic digestion 293 of micro-aerated sludge and control. As can be seen a clear decrease in the VSS content 294 with time was observed from the beginning of the process, in which the hydrolytic stage 295 takes place, achieving low values of this parameter, especially in the case of the pre-aerated 296 sludge. Similar trends in the evolution of VSS with time were reported by Diak et al. ${ }^{[41]}$, 297 although final VSS values close to $15000 \mathrm{mg} / \mathrm{L}$ were obtained in this case, being this value 298 much higher than those reached in the present work

299 Figure 8 shows the variation of methane production (measured as accumulated $\mathrm{CH}_{4}$ in $300 \mathrm{~mL} / \mathrm{g}$ VSS added) as a function of the digestion time, which allows evaluating the volume 301 of methane produced per each gram of VSS added at the beginning of the anaerobic 302 digestion process. According to the data shown in this Figure, a significant increase (110\%) 303 in the production of methane was obtained when applying to the mixed sludge aerobic 304 hydrolysis compared to the digestion process of non-aerated sludge. These results are 305 consistent with the evolution of the COD and VSS presented previously. Lower increments 306 in the methane yield $(21 \%)$ were previously reported during the anaerobic co-digestion of 307 brown water and food waste (during 45 day operation time) previously subjected to an 308 micro-aerobic pretreatment with an aeration intensity of $0.0375 \mathrm{~L} \mathrm{O}_{2} / \mathrm{L}_{\text {reactor }} /$ day. ${ }^{[41]}$

\section{CONCLUSIONS}


312 This study demonstrated that biological hydrolysis by micro aeration of mixed sludge from

313 urban wastewater treatment plants is an effective pretreatment of this waste for its

314 subsequent anaerobic digestion. The most efficient aeration level to increase significantly

315 the methane yield of the micro aerated sludge compared to a control without pre-aeration

316 was $0.35 \mathrm{vvm}$. Although higher COD increases and VSS decreases were found at $60 \mathrm{~h}$ of

317 micro aeration, the above parameters did not vary significantly with respect to the values

318 found at $48 \mathrm{~h}$. Therefore, it would be necessary carefully evaluate the need to extend the

319 aeration for more than $48 \mathrm{~h}$ since the process improvement was not significantly increased

320 after 2 days of aeration. The application of a hydrolysis by micro aeration also allowed

321 stimulating the production of exoenzymes that carried out the degradation of slowly

322 biodegradable compounds which were otherwise resistant to degradation under completely

323 anaerobic conditions.

\section{ACKNOWLEGMENTS}

326

327 The authors wish to express their gratitude to FONDECYT Project No. 1030315 (Chile) for 328 providing financial support.

\section{REFERENCES}

332 [1] Appels, L.B. Principles and potential of the anaerobic digestion of waste-activated 333 sludge. Prog. Energy Combust. Sci. 2008, 34(6), 755-781. 
334 [2] Fonoll, X.; Astals, S.; Dosta, J.; Mata-Alvarez, J. Anaerobic co-digestion of sewage 335 sludge and fruit wastes: Evaluation of the transitory states when the co-substrate is 336 changed. Chem. Eng. J., 2015, 262, 1268-1274,

337 [3] Huiliñir, C.; Montalvo, S.; Guerrero, L. Biodegradability and methane production from 338 secondary paper and pulp sludge: Effect of fly ash and modeling. Water Sci. Technol. $339 \quad \mathbf{2 0 1 5}, 72(2), 230-237$.

340 [4] Pilli, S.; Bhunia, P.; Yan, S.; LeBlanc, R.J.; Tyagi, R.D.; Surampalli, R.Y. Ultrasonic 341 pretreatment of sludge: a review. Ultrason. Sonochem. 2011, 18(1), 1-18.

342 [5] Zhang, L.; Zhang, Y.; Zhang, Q.; Verpoort, F.; Cheng, W.; Cao, L.; Li, M. Sludge gas 343 production capabilities under various operational conditions of the sludge thermal 344 hydrolysis pretreatment process. J. Energy Inst. 2014, 87(2), 121-126.

345 [6] Garrido-Baserba, M.; Molinos-Senante, M.; Abelleira-Pereira, J. M.; Fdez-Güelfo, L. 346 A.; Poch, M.; Hernández-Sancho, F. Selecting sewage sludge treatment alternatives in 347 modern wastewater treatment plants using environmental decision support systems. J. $348 \quad$ Cleaner Product. 2015, 107, 410-419.

349 [7] Bolzonella, D.; Pavan, P.; Battistoni, P.; Cecchi, F. Mesophilic anaerobic 350 digestion of waste activated sludge: influence of the solid retention time in the 351 wastewater treatment process. Process Biochem. 2005, 40(3-4), 1453-1460.

352 [8] Lee, I-S.; Parameswaran, P.; Rittmann. B.E. Effects of solids retention time on 353 methanogenesis in anaerobic digestion of thickened mixed sludge. Bioresour. Technol. $354 \quad$ 2011, 102(22), 10266-10272.

355 [9] Pérez - Elvira, S.I.; Fernández-Polanco, M.; Fernández-Polanco, F. Enhancement of the 356 anaerobic digestion of sludge: comparisons of four different strategies. Water Sci. 357 Technol. 2011, 64(2), 375-383. 
[10] Tiehm, A.; Nickel, K.; Zellhorn, M.; Neis, U. Ultrasonic waste activated sludge disintegration for improving anaerobic stabilization. Water Res., 2001, 35(8), 20032009.

[11] Zhu, M.; Lu, F.; Hao, L.P.; He, P.J.; Shao, L.M. Regulating the hydrolysis of organic wastes by micro-aeration and effluent recirculation. Waste Manage. 2009, 29(7), 20422050.

[12] Ruíz, J.E.; Méndez, J.M.; Alvarado, A.; Martínez, S.A. Effect of low temperature thermal pre-treatment on the solubilization of organic matter, pathogen inactivation and mesophilic anaerobic digestion of poultry sludge. J. Environ. Sci. Health Pt. A. 2005, 47(12), 1795-1802.

[13] Carrère, H.; Bougrier, C.; Castets, D.; Delgenès, J.P. Impact of initial biodegradability on sludge anaerobic digestion enhancement by thermal pretreatment. J. Environ. Sci. Health Pt. A. 2008, 43(13), 1551-1555.

[14] Bien, J.B.; Malina, G.; Bien, J.D.; Wolny, L. Enhancing Anaerobic Fermentation of Sewage Sludge for Increasing Biogas Generation. J. Environ. Sci. Health Pt. A. 2004, 39(4), 939-949.

[15] Prince-Pike, A.; Wilson, D.I.; Baroutian, S.; Andrews, J.; Gapes, D.J. A kinetic model of municipal sludge degradation during non-catalytic wet oxidation. Water Res. $\mathbf{2 0 1 5}, 87,225-236$.

[16] Zhen, G.; Lu, X.; Li, Y-Y.; Zhao, Y. Combined electrical-alkali pretreatment to increase the anaerobic hydrolysis rate of waste activated sludge during anaerobic digestion. Appl. Energy 2014, 128, 93-102.

[17] Braguglia, C.M.; Gianico, A.; Mininni, G. Comparison between ozone and ultrasound disintegration on sludge anaerobic digestion. J. Environ. Manage. 2012, 95, 139-143. 
[18] Cesaro, A.; Belgiorno, V. Pretreatment methods to improve anaerobic 383 biodegradability of organic municipal solid waste fractions. Chem. Eng. J., 2014, 240, 24-37.

[19] Guellil, A.; Boualam, M.; Quiquampoix, H.; Ginestet, P.; Audic, P.; Block, J.C. Hydrolysis of wastewater colloidal enzymes extracted from activated sludge flocs. Water Sci. Technol. 2001, 43(6), 33-40.

[20] Whittington-Jones; K.J., Molwantwa, J.B.; Rose, P.D. Enhanced hydrolysis of carbohydrates in primary sludge under biosulfidogenic conditions. Water Res. 2006, 40(8), 1577-1582.

[21] Botheju, D.; Bakke, R. Oxygen Effects in Anaerobic Digestion - A Review. The Open Waste Manage J. 2011, 4, 1-19.

[22] Kato, S.; Haruta, S.; Cui, Z. J.; Ishii, M.; Igarashi, Y. (2005), Stable coexistence of 2005, 71(11), 7099- 7106.

[23] Mshandete, A.; Bjornsson, L.; Kivaisi, A.K.; Rubindamayugi, S.T.; Mattiasson, B. Enhancement of anaerobic batch digestion of sisal pulp waste by mesophilic aerobic pretreatment. Water Res. 2005, 39(8), 1569-1575.

[25] Gerritse, J.; Schut, F.; Gottschal, J.C. Mixed chemostat cultures of obligately aerobic and fermentative or methanogenic bacteria grown under oxygen limiting conditions.

[24] Nguyen, P.H.L.; Kuruparan, P.; Visvanathan, C. Anaerobic digestion of municipal solid waste as a treatment prior to landfill. Bioresour. Technol. 2007, 98(2), 380-387. FEMS Microbiol. Lett. 1990, 66(1-3), 87-89. 
404 [26] Jenicek, P.; Keclik, F.; Maca, J.; Bindzar, J. Use of micro aerobic conditions for the 405 improvement of anaerobic digestion of solid wastes. Water Sci. Technol. 2008, 58, $406 \quad 1491-1496$.

407 [27] Jenicek, P.; Celis, C.A.; Koubova, J.; Ruzickova, I. Change in the digested sludge 408 quality at microaerobic digestion. J. Residuals Sci. Technol. 2011, 8(2), 39-44.

409 [28] Montalvo, S.; Huiliñir, C.; Ojeda, F.; Castillo, A.; Lillo, L.; Guerrero, L. Microaerobic 410 pretreatment of sewage sludge: Effect of air flow rate, pretreatment time and 411 temperature on the aerobic process and methane generation Int. Biodeterior. $412 \quad$ Biodegrad. 2016, 110, $1-7$.

413 [29] American Public Health Association (APHA). Standard Methods for the Examination 414 of Water and Wastewater, 20 $0^{\text {th }}$ ed.; American Public Health Association/American 415 Water Works Association/Water Environment Federation, Washington DC, 2012.

416 [30] Gerritse, J.; Gottschal, J.C. Two-membered mixed cultures of methanogenic and 417 aerobic bacteria in $\mathrm{O}_{2}$ limited chemostats. J. Genetic Microbiol. 1993, 139(8), 1853$418 \quad 1860$.

419 [31] Conklin, A.; Bucher, R.; Stensel, H.D.; Ferguson, J. Effects of oxygen exposure on $420 \quad$ anaerobic digester sludge. Water Environ. Res. 2007, 79(4), 396-405.

421 [32] Celis-Garcia, M. L.; Ramirez, F.; Revah, S.; Razo-Flores, E.; Monroy, O. Sulphide 422 and oxygen inhibition over the anaerobic digestion of organic matter: influence of 423 microbial inmobilization type. Environ. Technol. 2004, 25(11), 1265-1275.

424 [33] Gerardi, M.H. The Microbiology of Anaerobic Digesters; Wiley- Interscience, John 425 Wiley \& Sons, Inc., Publication: New Jersey, 2003; 177 pp. 
426 [34] Miron, Y.; Zeeman, G.; van Lier J.; Lettinga, G. The role of sludge retention time in 427 the hydrolysis and acidification of lipids, carbohydrates and proteins during digestion 428 of primary sludge in CSTR systems. Water Res. 2000, 34(5), 1705-1713.

429 [35] Markou, G. Improved anaerobic digestion performance and biogas production from 430 poultry litter after lowering its nitrogen content. Bioresour. Technol. 2015, 196, 726$431 \quad 730$.

432 [36] Yenigün, O; Demirel, B. Ammonia inhibition in anaerobic digestion: a review. 433 Process Biochem. 2013, 48(5-6), 901-911.

434 [37] Burgess, J.E.; Pletschke, B.I. Hydrolytic enzymes in sewage sludge treatment. 435 Grahamstown: Department of Biochemistry and Biotechnology, Rhodes University, $436 \quad$ South Africa, 2008.

437 [38] Lim, J.W.; Wang, J.Y. Enhanced hydrolysis and methane yield by applying 438 microaeration pretreatment to the anaerobic co-digestion of brown water and food 439 waste. Waste Manage. 2013, 33(4), 813-819.

440 [39] Johansen, J.E.; Bakke, R. Enhancing hydrolysis with microaeration. Water Sci. $441 \quad$ Technol. 2006, 53(8), 43-50.

442 [40] Diak, J.; Örmeci, B.; Kennedy, K.J. Effect of micro-aeration on anaerobic digestion of 443 primary sludge under septic tank conditions. Bioprocess Biosyst. Eng. 2013, 36(4), $444 \quad 417-424$. 


\section{FIGURE CAPTIONS}

457 Figure 1. Variation of the methane production with time for the different experiments

458 carried out in the assay I

459 Figure 2. Evolution of the soluble protein concentration during the micro-aeration process

460 at $0.3 \mathrm{vvm}$

461 Figure 3. Evolution of the total sugars concentration during the micro-aeration process at

$4620.3 \mathrm{vvm}$

463 Figure 4. Effect of the aeration level on the $\mathrm{COD}_{\mathrm{S}}$ concentrations during the micro-aerobic 464 hydrolysis of the four samples of mixed sludge from urban wastewaters

465 Figure 5. Effect of the aeration level on the VSS contents during the micro-aerobic 466 hydrolysis of the four samples of mixed sludge from urban wastewaters

467 Figure 6. Evolution of the total $\mathrm{COD}\left(\mathrm{COD}_{\mathrm{T}}\right)$ with time in the anaerobic digestion 468 processes of the non-aerated and micro-aerated mixed sludge

469 Figure 7. Evolution of the VSS with time in the anaerobic digestion processes of the non470 aerated and micro-aerated mixed sludge.

471 Figure 8. Variation of the methane production $\left(\mathrm{mL} \mathrm{CH}_{4} / \mathrm{g}\right.$ VSS) with time in the anaerobic 472 digestion processes of the non-aerated and micro-aerated mixed sludge. 
476

477

478

479

480

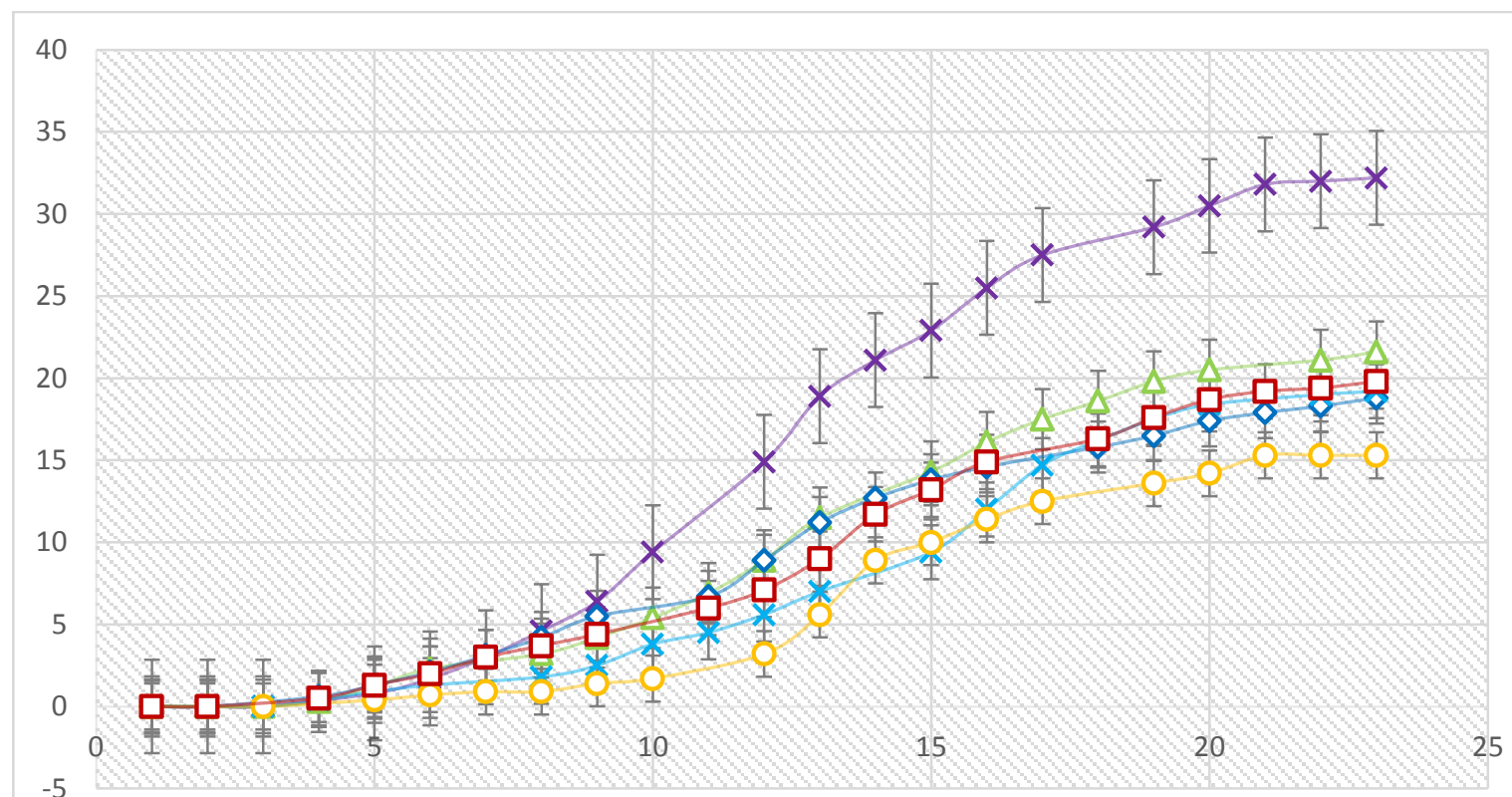

481 Figure 1.

482

483

$$
\begin{aligned}
& -\Delta \text { air 0,1 vvm } \rightarrow \text { air 0,3 vvm }- \text { air 0,5 vvm } \\
& \times- \text { control 0,1 vvm }- \text { - control 0,3 vvm }-\square \text { control 0,5 vvm }
\end{aligned}
$$




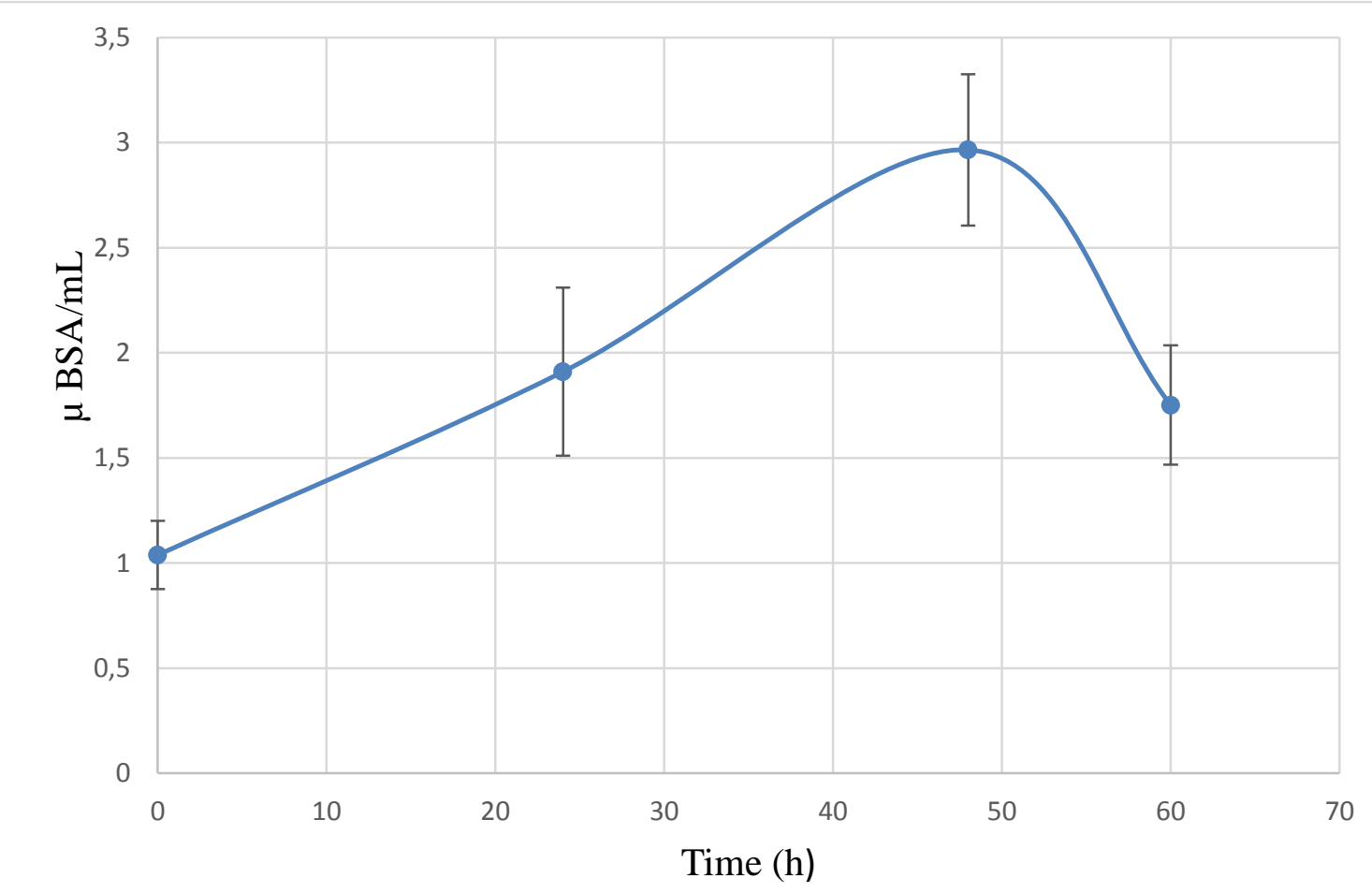

484

485 Figure 2.

486 


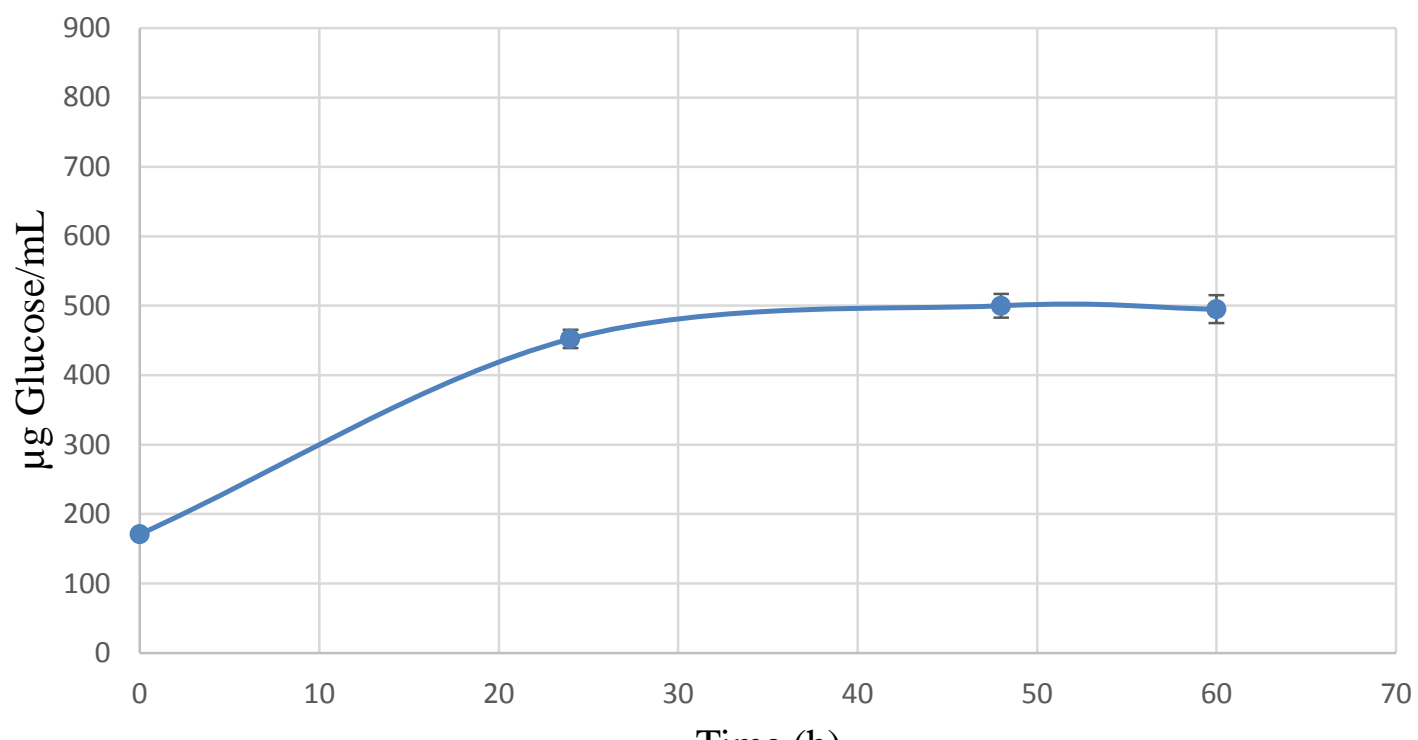

Time (h)

487

488 Figure 3.

489

490 
491

(A)

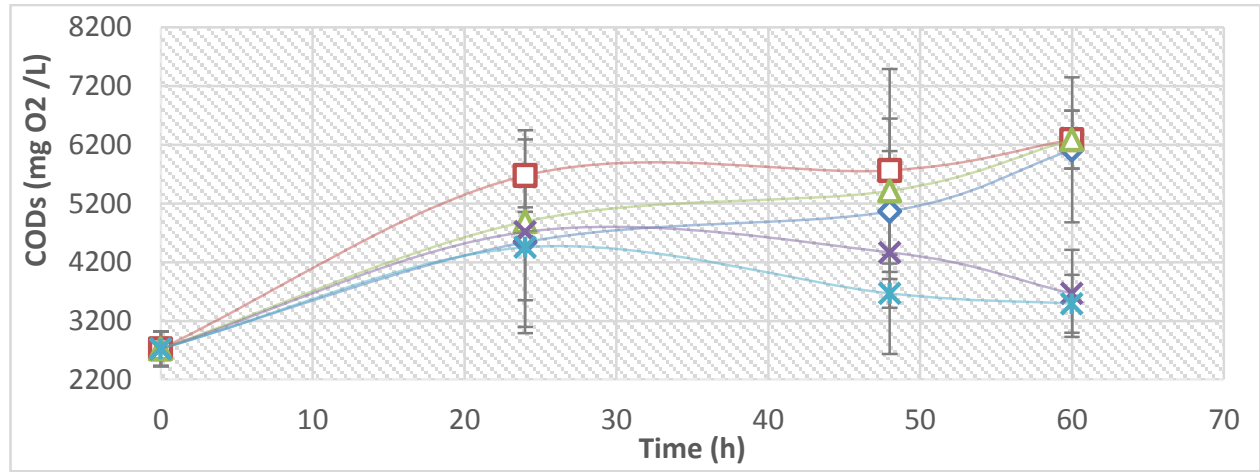

492

(B)

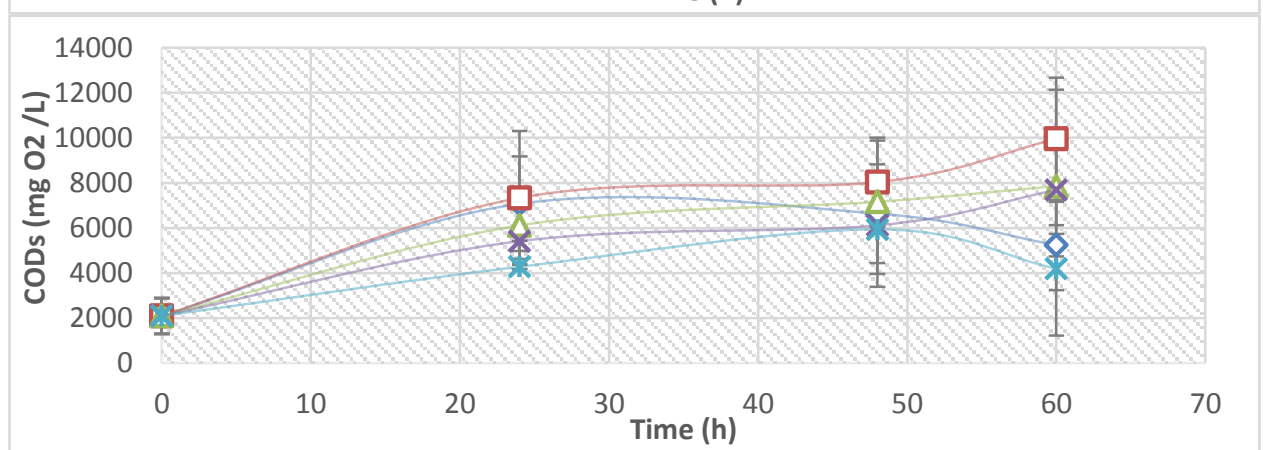

(C)

493

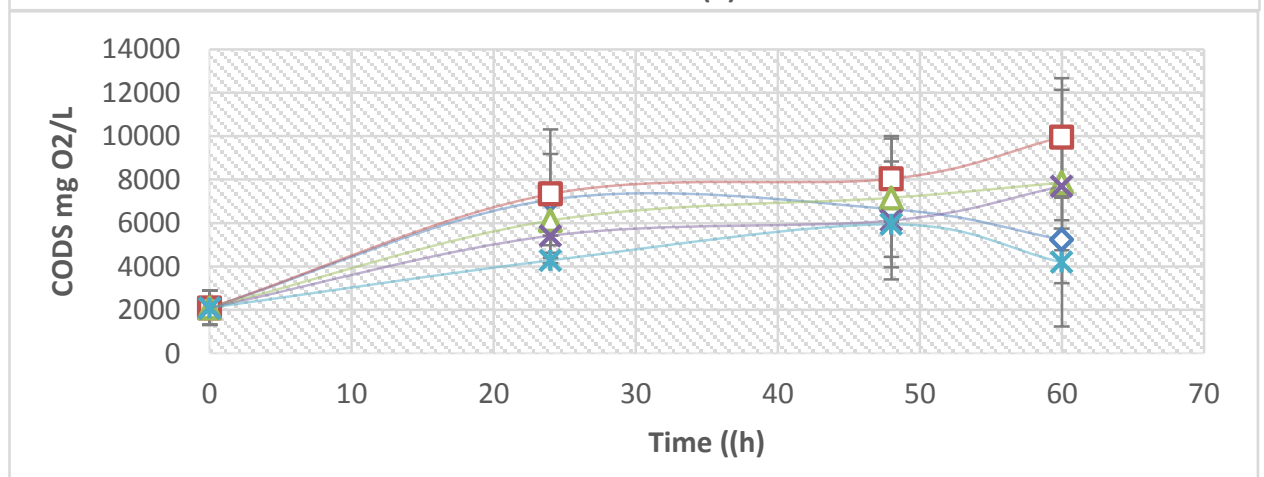

(D)

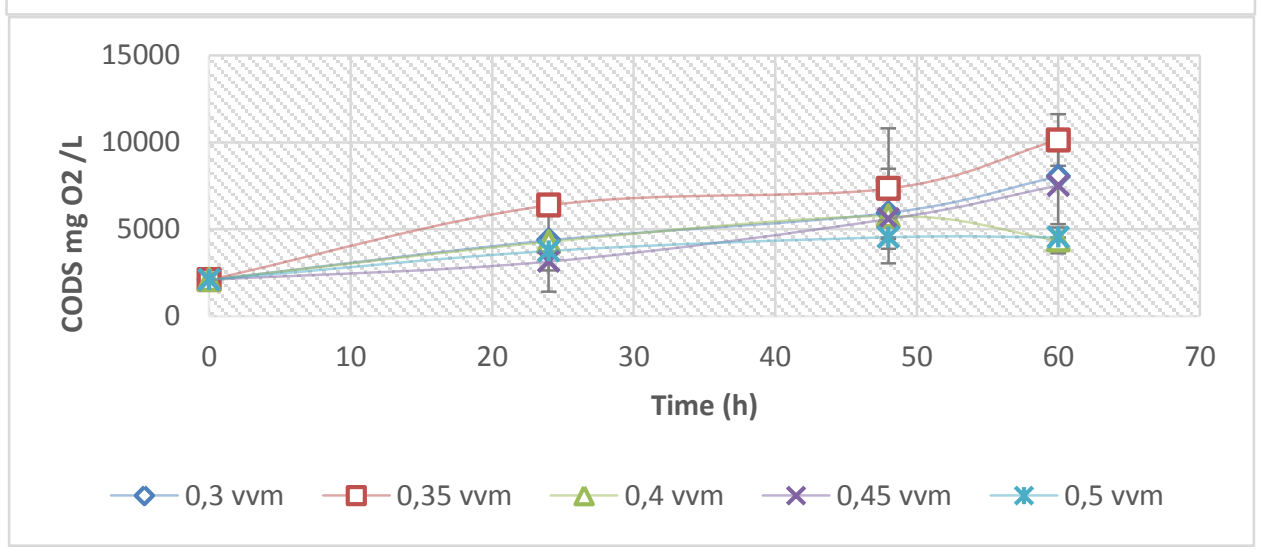

495 Figure 4. 
496

( (D)

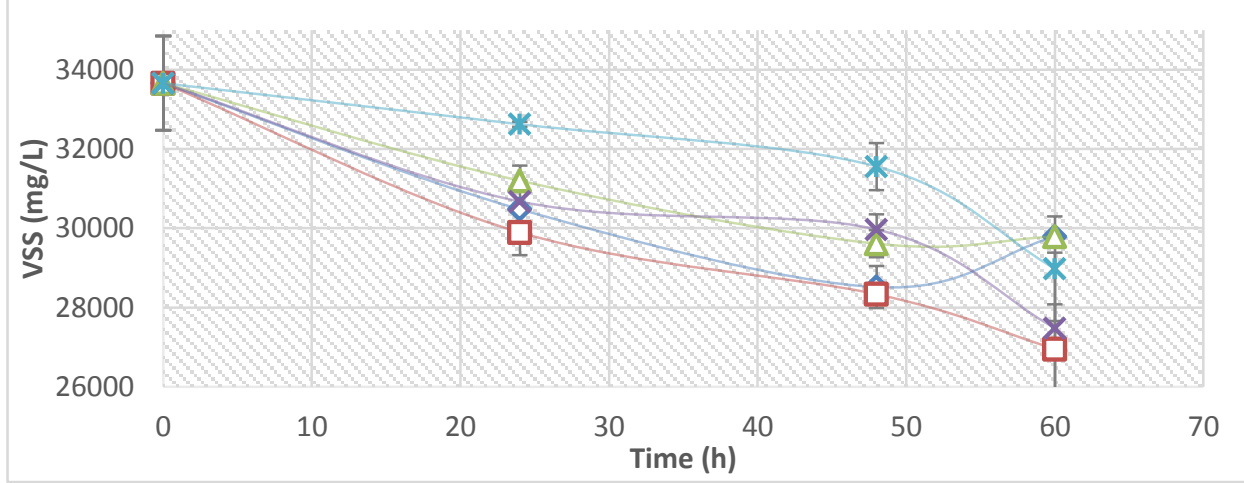

(B)

497

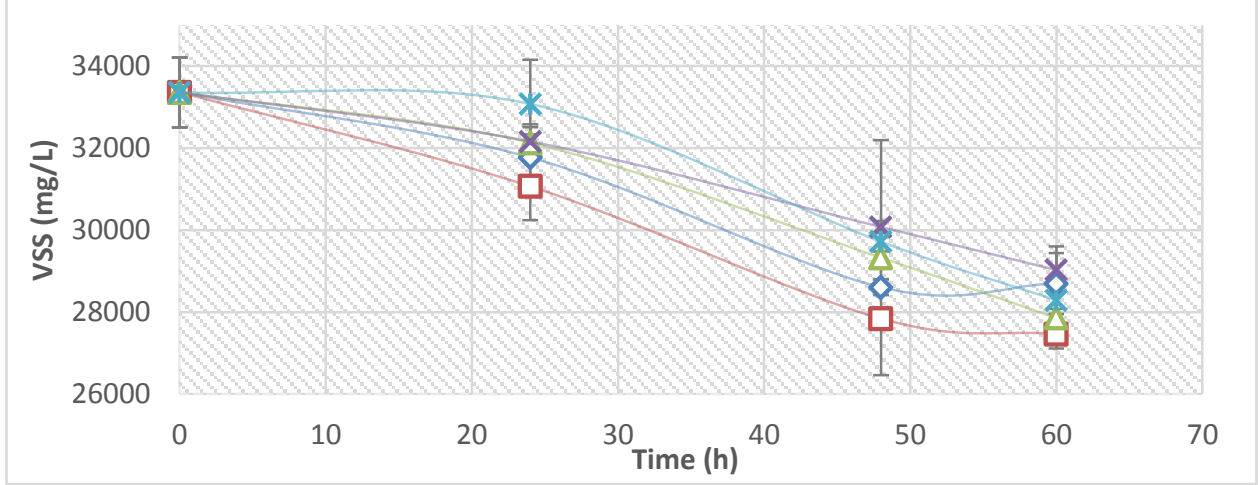

(C)

498

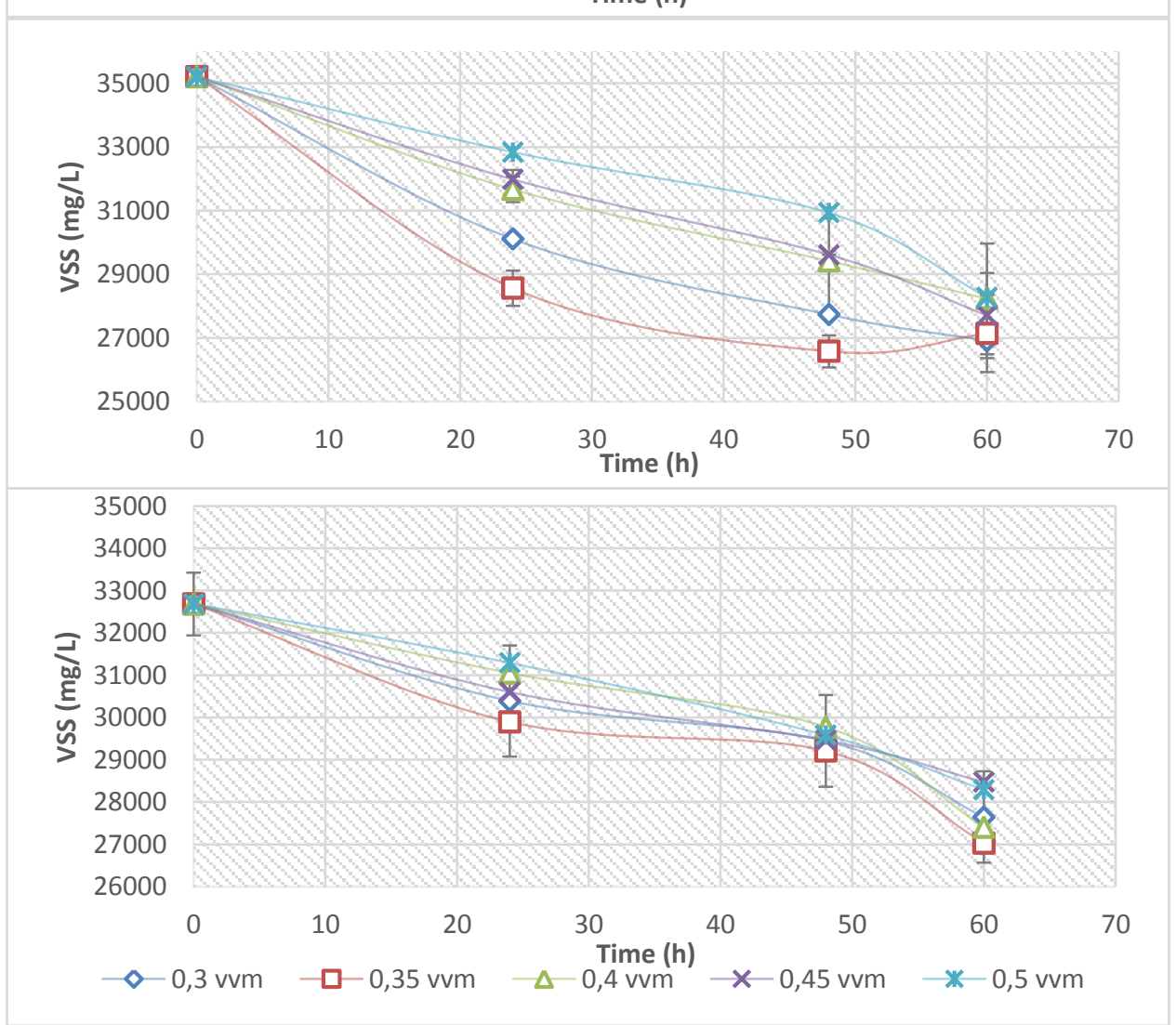

Figure 5. 


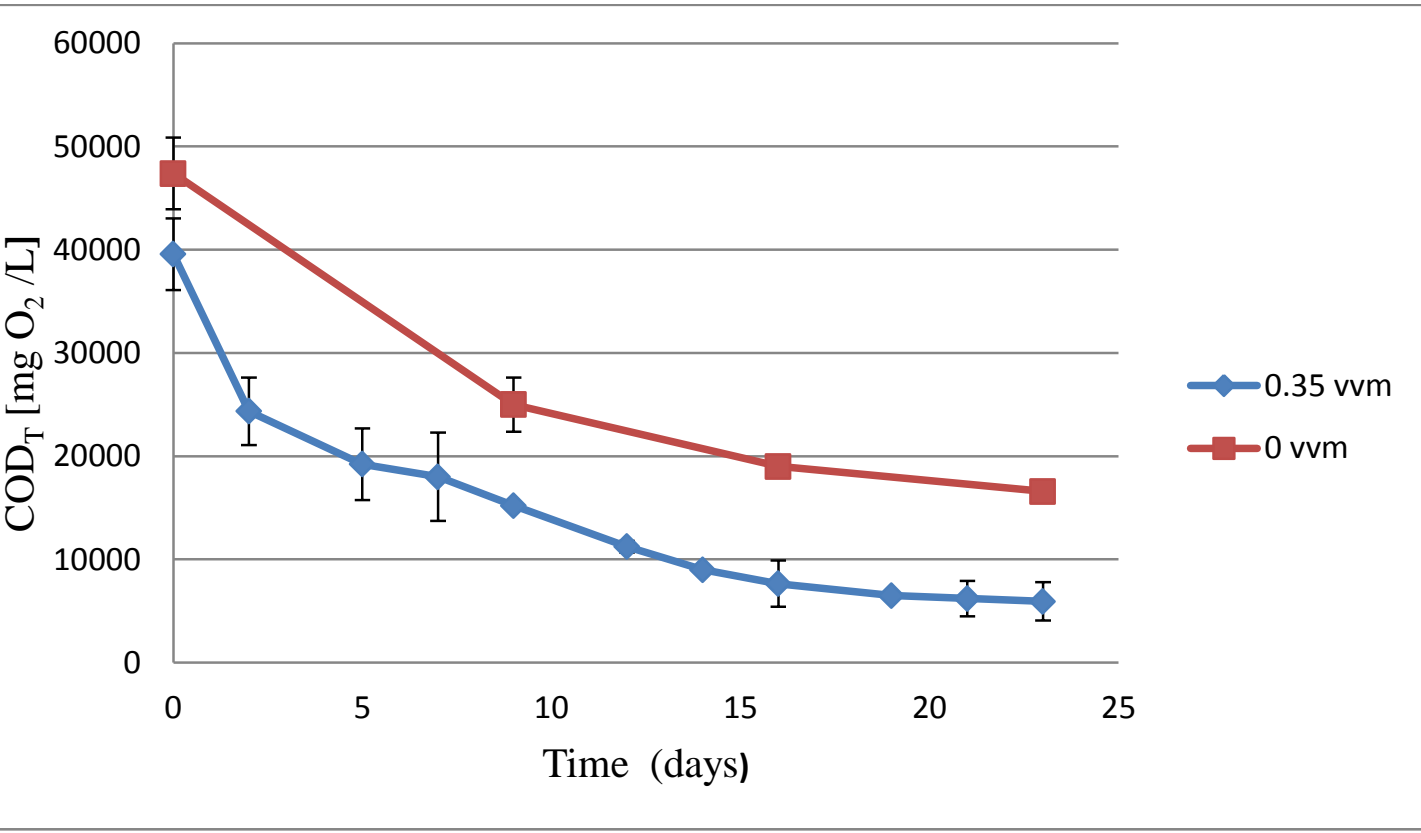

503 Figure 6.

504

505

506

507

508

509

510

511 


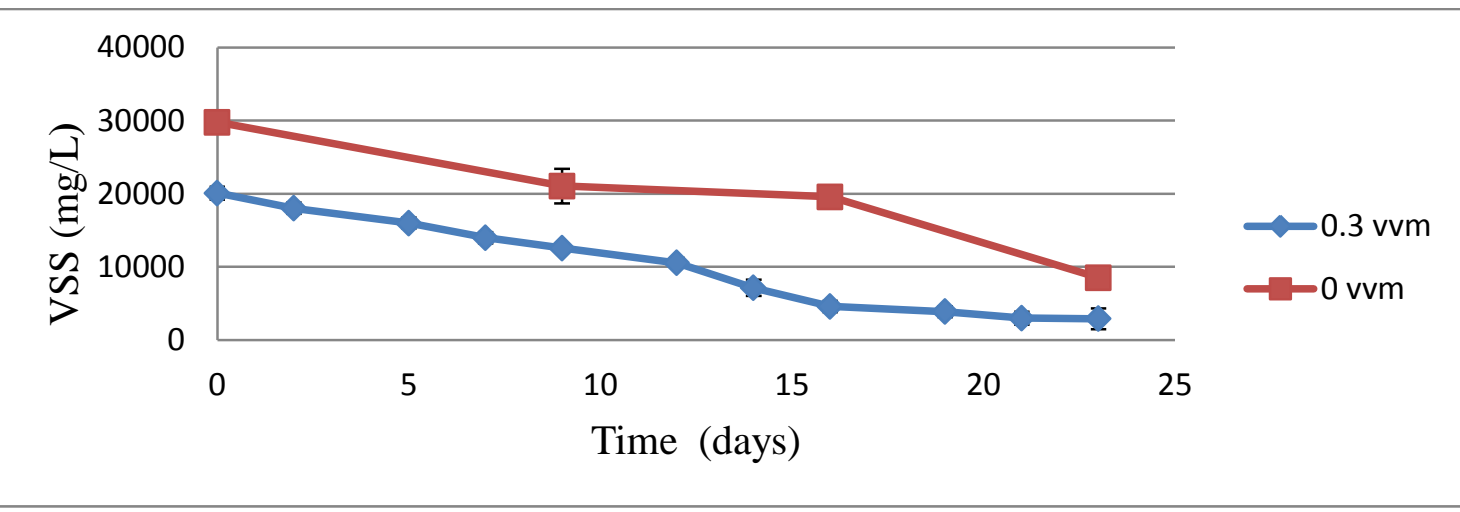

512

513 Figure 7.

514

515

516

517

518

519

520

521

522

523 


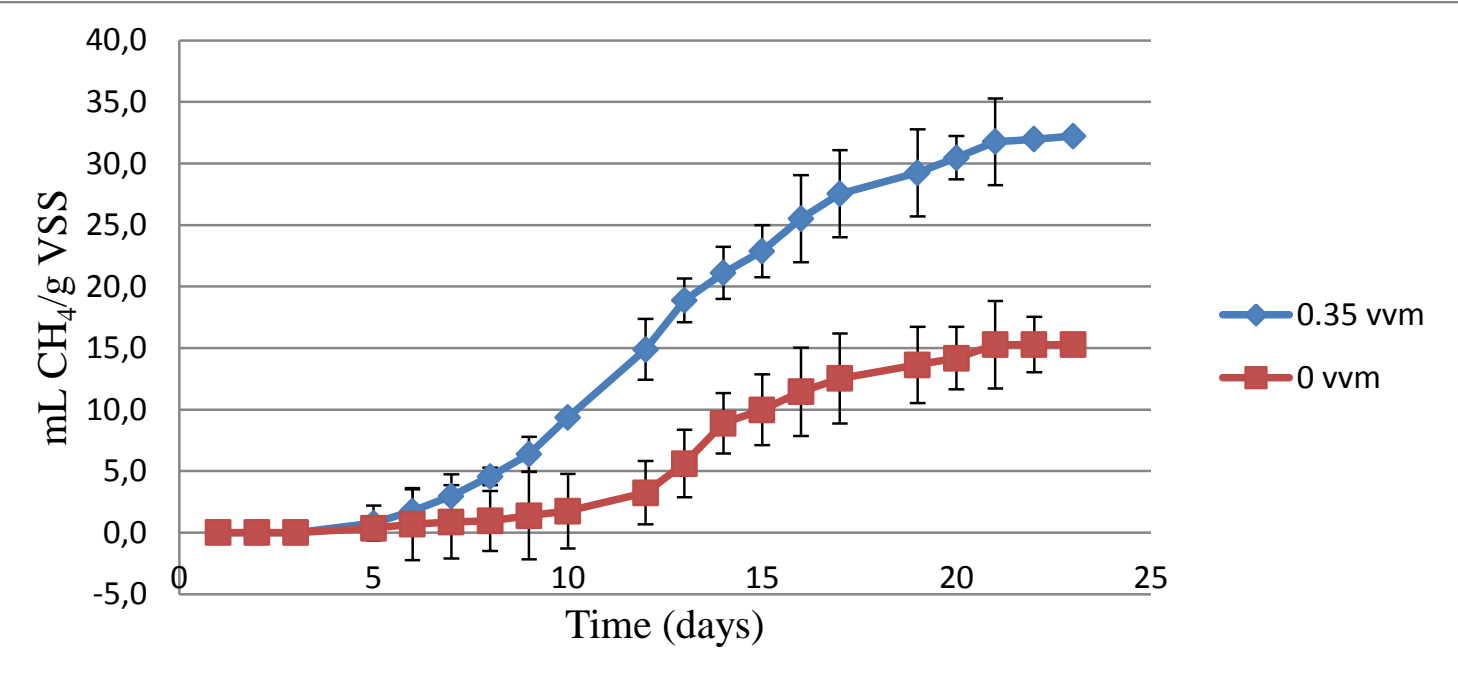

525 Figure 8.

526

527

528

529

530

531

532

533

534

535

536

537

538

539

540 
541 Table 1. Operational conditions of the three experimental runs carried out

\begin{tabular}{|c|c|c|c|c|}
\hline \# Assay & $\begin{array}{c}\text { Aeration level } \\
\text { (vvm) }\end{array}$ & $\begin{array}{c}\text { Aeration Time } \\
\text { (hours) }\end{array}$ & $\begin{array}{c}\text { Operating } \\
\text { Temperature } \\
\left({ }^{\circ} \mathrm{C}\right)\end{array}$ & $\begin{array}{c}\text { Batch anaerobic } \\
\text { digestion at } \\
35^{\circ} \mathrm{C}\end{array}$ \\
\hline \multirow{4}{*}{ I } & 0 & 48 & 35 & YES \\
\hline & 0.1 & 48 & 35 & YES \\
\hline & 0.3 & 48 & 35 & YES \\
\hline & 0.5 & 48 & 35 & YES \\
\hline \multirow{5}{*}{ III } & 0.3 & $24-48-60$ & 35 & $\mathrm{NO}^{*}$ \\
\hline & 0.35 & $24-48-60$ & 35 & $\mathrm{NO}^{*}$ \\
\hline & 0.4 & $24-48-60$ & 35 & $\mathrm{NO}^{*}$ \\
\hline & 0.45 & $24-48-60$ & 35 & $\mathrm{NO}^{*}$ \\
\hline & 0.5 & $24-48-60$ & 35 & $\mathrm{NO}^{*}$ \\
\hline \multirow[t]{2}{*}{ III } & 0 & 48 & 35 & YES \\
\hline & 0.35 & 48 & 35 & YES \\
\hline
\end{tabular}


550 Table 2. Influence of aeration on the final $\mathrm{pH}$ of the reactor

\begin{tabular}{|c|c|c|}
\hline Aeration level $[\mathrm{vvm}]$ & Initial $\mathrm{pH}(\mathrm{t}=0 \mathrm{~h})$ & Final $\mathrm{pH}(\mathrm{t}=48 \mathrm{~h})$ \\
\hline 0 & $5.80 \pm 0.05$ & $6.00 \pm 0.04$ \\
\hline 0.35 & $5.80 \pm 0.05$ & $6.20 \pm 0.03$ \\
\hline
\end{tabular}

551

552

553

554

555

556

557

558

559

560

561

562

563

564

565

566

567

568

569 
Table 3. Variation of the concentration of total ammonia (TAMON), $\mathrm{COD}_{\mathrm{T}}, \mathrm{COD}_{\mathrm{S}}$ and

571 VSS after the micro-aeration and non-aeration processes

\begin{tabular}{|c|c|c|c|c|}
\hline \multirow{2}{*}{$\begin{array}{c}\text { Parameter } \\
(\mathrm{mg} / \mathrm{L})\end{array}$} & $\begin{array}{c}\text { Aeration level } \\
(\mathrm{vvm})\end{array}$ & \multicolumn{2}{|c|}{ Aeration time } & Increase (+) o decrease (-) (\%) \\
\hline \multirow{3}{*}{ TAMON } & \multirow{2}{*}{0} & 300 & 375 & \multirow{2}{*}{$25(+)$} \\
\cline { 2 - 5 } & 0.3 & 300 & 920 & $207(+)$ \\
\cline { 2 - 5 } & 0 & 48900 & 47433 & $3(-)$ \\
\hline \multirow{2}{*}{ COD $_{\mathrm{T}}$} & 0.3 & 48900 & 39609 & $19(-)$ \\
\cline { 2 - 5 } & 0 & 2500 & 3175 & $27(+)$ \\
\hline COD & 0.3 & 2500 & 6250 & $150(+)$ \\
\cline { 2 - 5 } & 0 & 33457 & 29776 & $11(-)$ \\
\hline VSS & 0.3 & 33457 & 20074 & $40(-)$ \\
\cline { 2 - 5 } & & & & \\
\hline
\end{tabular}

572

573

574

575

576

577

578

579

580 